\title{
STANDING IN LINE AT SUNDAY MATINEE
}

Charles Casey Martin

an elegy for Ethel Thompson Roberts

Across the alley, Baptist children in Sunday clothes

Play on the church lawn. Though closed and locked

The shops along Central Avenue

Are still in business. We stand in line. An usher

Stands on a ladder and spells Held Over in marquee fonts.

One of the E's is a backward 3. I point to you

And hold up two fingers. The cashier says "five"

And shows the palm of her hand. We stand

In line. We prefer

The film to the book: if the heroine died

The heroine doesn't have to die

Though applause simply adds to the confusion

As we crowd through the exit,

Holding hands, squinting in the sunlit lobby.

Surprised:

That darkness isn't always night,

That death wasn't the final absence,

Closed by the end as the body heals an open grave.

We stand in line. Remembering

The circle of children, hand in hand in hand,

Who all fell singing into the churchyard grass.

And our memory is the beginning

Of a past described by missing faces:

The four or five empty seats

In a theatre filled for the occasion. 